\title{
The Impact of Technology-Aided Instruction on Motivation of Geometry Learners
}

\author{
Hamdi Serin ${ }^{1}$ \\ ${ }^{1}$ Department of Mathematics, Faculty of Education, Tishk International University, Erbil, Iraq \\ Correspondence: Hamdi Serin, Tishk International University, Erbil, Iraq. \\ Email: hamdi.serin@tiu.edu.iq
}

Doi: $10.23918 /$ ijsses.v7i3p63

\begin{abstract}
Rapid development of technology has made it inevitable to use it in the classes. As the scope of technology is wide and it is continuously renewed, it has brought changes in the way and style of using it also. The fact of how technology is implemented is one of the main factors affecting class management. In the applications of technology-aided education based on a behavioral approach, traditional lecturing method is supported, and motivation of the students is enhanced. In a class that is created by use of constructivist approach, student-centered studies are given more attention. Therefore, classroom management techniques will automatically change. Many students have difficulty in perceiving the key concepts in geometry and prefer to leave the geometry lessons without learning even the very basic terminology. Systematic geometry teaching might help students to obtain a better geometry knowledge and success since their motivation will rise. The study aims to show the facilitating role of technology-based teaching in increasing student motivation. Moreover, the current study tries to explain whether the use of technology in the classroom can increase geometry learning.
\end{abstract}

Keywords: Technology, Motivation, Geometry Learning, Classroom Management

\section{Introduction}

Burger \& Shaughnessy (1986) claim that sequencing methodology has positive influences on the students' successes and senses about themselves, the subjects, and relevant cognitive skills. If the learning process does not commence with a good start, then students will have motivation problems because the bad inauguration will form a negative generalization whatever the teacher strives to teach them. Additionally, the level of difficulty of the activities is very paramount. They may not draw students' care on the topic or might be very easy to show enough attention or might be very difficult to understand. The tasks used in teaching should involve reasonable challenges that students will be able to achieve; otherwise they are going to lose their motivation (Hoffer, 1986; Messick \& Reynolds, 1992; Mart, 2013a; Mart, 2017). Within this context, choosing a suitable methodology will affect the motivation of the learners.

Singleton \& Simmons (2001), in his research has found out that classroom mediums with computer support increase students' motivation and make the lessons much more enjoyable. Also, because the use of computer provides different and enhanced learning opportunities, it is thought that students will be more successful in the solution of the problems requiring scientific thinking. However, there are not many types of research that will support this thought. The studies held show that computers and other technologies generally impact the sensitive characteristics of the students rather than cognitive ones (Uyar, 2007). As a 
result, there are few studies regarding the effects of technologies on classroom management and the contradictory consequences proving that the effects of technologies are not known enough. The reduction of this ambiguity depends on the studies to be conducted in this field.

According to Usiskin (1982), many students have difficulty in perceiving the key concepts in geometry and prefer to leave the geometry lessons without learning even very basic terminology as he stated that the systematic geometry teaching might help students to obtain a better geometry knowledge and success since their motivation will rise. Most of the activities that are held in the classroom are influenced by the teacher's method of application. While planning to teach, previous data and new ones must be interacted with each other to make the information meaningful. This will facilitate students' learning in the classroom.

Researchers emphasize the elements related to motivation as much as cognitive and behavioral factors in the process of learning. Motivation has direct positive impact on success. Motivation is to be able to set up a psychological link between the target behavior and the student. Starting teaching and education without setting up this link, the efficiency of the activities is reduced [because] motivation is an important factor facilitating learning (Kaya, 2001; Mart, 2011). The increase in student's motivation will decrease the troubles and problems in the class, and so it affects class control in a positive way (Öncü, 2001). On the other hand, it must not be forgotten that motivation changes according to time, method, and way of teaching (Pintrich \& Dale 1996).

In the literature, there are a lot of articles regarding the positive influence of motivation on learning. However, the studies about how to use motivation in the planning of teaching because it is easier to measure the acquisition level of cognitive targets than the measurement of motivational objectives and gaining (Spitzer, 1996; Seah \& Bishop, 2000; Dede, 2003). This type of thinking originates from ignoring the importance of motivation or preference to choose the easy way. As Spitzer (1996) reported, it supports the idea mentioned above that only 1.5 pages are allotted for motivation subject in a book of 300 pages regarding learning. According to Spitzer, motivation is handled in the limits, like mostly drawing attention and directing students to learn. Motivation researches have shown that the changes and concepts like selfsufficiency, target orientation, and interest are related to students' beliefs in motivation. The persistence of students to learn and to study, eagerness and interest in the subjects taught, high level of self-sufficiency feelings about the capability to perform the applications and activities in the lessons, self-trust in themselves about success increase their motivation for learning and change their misjudgments against the concepts (Pintrich \& Dale 1996; Yin, et al. 2008).

As for the variances determining student's motivational faiths, they are their self-sufficiency beliefs in the performance-related to the task, importance of the task, and the feelings for the task (Pintrich \& De Groot, 1990). Self-sufficiency, too, is in an important position in the literature of self-arrangement learning. Selfsufficiency, in Stone's opinion (2000), is the belief that they carry to complete any task or to reach their aims (Schunk, 1991). It means that the stronger their self-sufficiency is, the more willing and faithful to learn they are (Bandura, 1986). According to Keskin and Orgun'a (2006), self-sufficiency is a significant feature of a person that will determine how a person thinks, feels, and behaves. Low self-sufficiency feeling is associated with depression, anxiety, and hopelessness. 
Additionally, such individuals have low self-confidence and carry pessimistic feelings about their successes and developments. On the other hand, strong sense of completion eases the perception of the problems and increases academic performance. The level of self-sufficiency can reduce or increase the drives to be able act. The individuals with high self-sufficiency can choose more sophisticated and risky tasks; their targets are high, and they show all endeavors to reach them (Keskin \& Orgun, 2006).

It will be much healthier to generate a task based on learning since the desire to perform a task may cause the anxiety to make a mistake for students. Pleasure and participation level of students rise by involvement in the classroom activities. It affects positively the classroom atmosphere that better be task-oriented with learning-based than in the situation of pre-eminence, (ego) predominance. Task-orientation facilitates the classroom management of teachers as students do not deal with other issues in the class, and they are aware of how to behave. Today, it is significant to measure the subjects related to motivation; especially mathematics course is very important in this sense. Math is given particular importance from including abstract concepts regarding mental actions.

Üredi (2005) talks about the positive impacts of the self-sufficiency process upon mathematical performance in different studies. Having high self-sufficiency belief affects individuals' cognitive processes and motivations by causing them to have much higher targets and persistency in their decisions (Locke \& Latham, 1990). The concept of anxiety is different from fear, and similar concepts with a specific object depended on fear (Armaner, 2003). Anxiety is to feel worried as if there were a danger, although there is no concrete object, and this is an unhealthy reaction. As for fear, it is a protective reaction given healthily to any concrete danger (Atabek, 2000).

In instructional education design models, it is seen that the factors toward learning, understanding, and skills are taken into consideration much more comparing them to motivational elements. According to Main (1993) the reason for this is that education strategies in affective field and the development of activities are slower than the development of psychomotor and cognitive fields, particularly (Dede, 2003). Therefore, instructional design is firstly applied in cognitive part. The titles regarding effective parts are examined under two groups. The first one is related to changing attitudes, values, and beliefs. The latter covers the individual's thoughts about the subject to be learnt. The aim here is to motivate the students to learn the subject (Main, 1993). Wu and Huang (2007) have compared a teacher-centered medium with technological support to student-centered medium from some variables. In the study performed in Taiwan, the computer has been presented as a visual device by the use of teachers in a teacher-centered medium; as for student-centered medium, students have used the computers. In conclusion, it has been witnessed that there are no important differences between groups, and unwanted behaviors are less in the teachercentered medium. However, on the other hand, motivation, self-confidence, and the characteristics of capability to make independent studies are higher in student-centered medium.

The equipment and tools that are used in teaching and educational activities increase the interest of the students in the lessons (Yalın, 2000; Mart, 2013b). Utilizing technological aids in teaching mathematics will help students gain a positive attitude toward math and will increase efficiency and permanence of education and teaching. 


\section{The Use of Interactive Whiteboards as an Instructional Tool and Its Effect on Student Engagement in Learning Geometry}

It is related to the settlement arrangement of the students, whether they are active or passive in the classroom (Saban, 2002). If teachers want to provide active participation of the students, then it is required to make changes according to the different conditions. Classroom settlement arrangements can be listed as individual classroom settlement, U style, lined-order, cluster style and round table (McKeinze, 1997; Bal et al., 2002; Özden, 2002).

Everyday new tools are added to the inventory of education as parallel to the innovations in the technology. It becomes fundamental, by using technology as an aid, to turn abstract content into concrete ones with visual and audial supports. Computers can be utilized to give concrete content for primary levels, and as for secondary grades it can be used to teach abstract concepts. The activities, that were used to be performed by tools like paper, pen, and ruler, have been implemented much more efficiently by using computers (Baki, 2002).

In a study, Cogill (2003) has stated that interactive technologies to be used for the benefit of mathematics must be used differently in accordance with the subjects. It has been agreed that the pedagogical approach must be adopted according to the content. On the other hand, besides technological aids, Sutherland (2004) has mentioned that gestures and mimes have direct supportive effect on education. Abrahamson (2004) has said that this plays an important role in the perception of mathematics.

Most of the mathematical concepts are abstract concepts requiring high level of cognitive activities. Computers, mostly, can make abstract concepts concrete by making them visual items. In this way, most of the sophisticated mathematical concepts turn into concrete ones, and this makes it easy to understand because of direct positive effects on learning and teaching (Baki, 2000). Especially, children at young ages are not ready to deal with abstract concepts because of their developmental features. Thus, if the convenient technology is used according to their age and level, then they will be ready for the perception of such concepts and eager to learn (Tukun et al., 2011).

Calculators, computer algebra systems, dynamic geometry software, java applications, electronic tables (spreadsheets) and interactive presentation devices are the components of high-quality mathematics education (NCTM, 2008). Computer algebra systems like Derive, Mathematical, Maple or MuPAD are the technological devices to be used in effect for math (Tutkun et al., 2011). These software packages can be used for discovery-based learning and experimental practices in the classroom medium. These systems have combined the skills of symbolic, numerical, and graphic drawing by providing an interactive medium for user to discover the problems in the math and statistics (Aktümen \& Kaçar, 2008).

Such technologies of dynamic geometry and algebra software make an influence on students' learning in a positive way as well as they can be used to respond to different and new understanding and to create an efficient classroom and teaching medium (Tutkun et al., 2011). It is necessary for teachers to have full usability control on computer-aided mathematics teaching (CAMT) to be able to obtain required efficiency and contribution of those technologies. Teachers, in-service training, must be taught not only how to use those technologies but also the methods how to integrate those for efficient teaching (Kabaca et al., 2010). 
It is vital to learn and perceive the basic concepts of mathematics. Geometry is an important branch of the theoretical system of mathematics in which definitions play critical roles and shapes and space are studied (Gökbulut \& Ubuz, 2013). Recognition of geometrical objects and knowing their features, finding the correlations between these objects, and proving geometrical propositions are the main goals both in twodimensional geometry and three dimensional (Baki, et al., 2008). Bozkurt and Koç (2012) have said that the basic concepts of geometry are shapes and objects and it is necessary to have the schemes related to these concepts in mind to be able to acquire them. As it is known, one of the sub-branches of geometry is space geometry, and it is quite difficult to teach it by using traditional tools like paper and pencil (Kösa, et al., 2008). Either two-dimensional drawings of a three-dimensional object are missing and cause optical illusions or different perceptions, or even they are perfect drawings, it is impossible to see the appearance of the shapes from different angles because of the static condition of the medium (Baki et al., 2008). It is likely to appear difficulties in learning due to two-dimensional drawings in teaching of prisms, which are three-dimensional objects. Parallel to the popularity of smart boards, use of dynamic mathematics software will be widespread, as well. The effects and contributions of smart boards to education are examined in the literature, and the results have shown that smart boards have positive effects on students' success and attitudes toward mathematics. It can be utilized from smart board from dynamic geometry software both by teacher use and single use of students in computer labs. So far, many researchers have searched for the effects of computer-aided education on different subjects of mathematics and have gained the positive results of suitable computer use. The meaning of suitable use of computers in education is that it must provide support for students' high-level cognitive skills (Karataş \& Güven, 2008).

There are a limited number of studies on surface area and volume of geometrical objects, and generally technology-aided methods and traditional ways have been compared. In the studies placed in the literature, although there is a consensus about the effects of technology-aided methods on the subject of surface area and volume of geometrical objects, there is no comparison about detection of which teaching method will be more efficient. Because of this reason, in this study, two technology-aided teaching methods, which are computer-aided teaching and smartboard-aided teaching will be compared, and it will be examined which one more efficient is.

\section{Dynamic Geometry Software}

Geometrical thinking is discussed in three cognitive processes, such as visualization, construction, and reasoning (Kösa, et al., 2008). With the development of software that will be used in geometry teaching and will support geometrical thinking, making use of technology has started to be widespread. Dynamic geometry software is (DGS) the specific software that is created to use in geometry education. Dynamic geometry mediums (DGS) have been designed to make Euclidian geometry concrete in an interactive and dynamic way (Leung, 2012). DGS provides visualization by objectification of abstract concepts; its dynamic shape provides opportunity for students to construct shapes, and while helping students notice geometrical relations, it assists with educational activities accepted by constructivist philosophy through one of the most important characteristics of DGS is the feature of dragging. It increases permanence by providing learning-by-application. It has been revealed out by many researchers that such interactive mediums contribute to teaching of geometry in much more effective way by setting up relation between teacher and student (Ubuz, et al., 2009). 
Discovery by the feature of dragging is a strong tool that supports reasoning (Leung, 2012). Dynamic geometry software increases the efficiency of teaching activities by the features that objectify geometric concepts, provide chance to use trial and error method, support student motivation, provide active participation students, are suitable for small groups. It is necessary to make use of computers and technology to increase success of students and to have an efficient education (Ertem, 1999).

The programs that are GeoGebra, Cabri3D, Geometer's Sketchpad, Cinderella, and Logo are some of those DGS. Current characteristics of DGS are as follows:

- Easier creation of geometrical shapes (including the shapes in analytic geometry lesson)

- Opportunity to measure to determine the properties of constructed shapes (Angle, circumference, length, square measures, etc.)

- Dragging (The most significant feature of DGS), extending, narrowing, and rotating the shapes on the screen (By means of this property, students can discover some unchanging features of shape while changing some features)

- Dynamical changes of pre-measured quantities during the movement of structure; by means of this feature, while watching the change of structure, it can be set up a hypothesis

- Opportunity to study all subjects of transformation geometry

- Not including any ready software or subject (Baki et al., 2008; Retold: Güven \& Karataş, 2003).

Wood and Ashfield (2008) have conducted a study on the use of interactive boards with the aim of creative learning and teaching. Interactive board methods that can increase and support pedagogical application through all class activities, including literacy and mathematics skills, are taken into consideration. Besides individual interviews with class teachers and teacher candidates and conduction of focal group discussions, by making observations in all classes it has been an opportunity to draw attention to the fact that the gathered data has a potential to the simplification of a much more creative approach in classroom activities. The data, in addition to interaction, temporariness, speed, capacity which are the specific characteristics of information and communication technologies, show the characteristics like increasing the speed of transmission and sessions.

Tataroğlu (2009) has conducted a study to determine how smart board use in mathematics affect academic success of $10^{\text {th }}$-grade students, attitudes, and self-sufficiency level toward mathematics. He has made use of both quantitative and qualitative data in the study in which he has worked with 124 students. Depending on the results gained from the data, it has been seen that smartboard use does not make significant difference in the academic level and self-sufficiency perceptions of students for the subject of quadratic functions among experimental and control groups; it has been detected that there is statistically significant difference among attitude levels for favor of experimental group.

Olkun, Atun, and Smith (2005) have used Tangram geometric games in a technology-aided medium and examined the effects of it on students' geometry learning. Two hundred twenty-four students from chosen five different schools have been given pre-test; 5 homogenous groups, two control, and three experimental groups, from two schools have arranged according to the test results. It has been suggested that although pre-test results of the students having computer at home are significantly high, it can be reinforced by 
using a fun computer game, Tangram. It has been inferred that it will be more effective to integrate the technologies that provide mathematical content and enjoyable mathematical discoveries for students.

In their study entitled 'Computer-aided Geometry Teaching for Secondary School $7^{\text {th }}$ Grade Students', Bintaş and Bağcivan (2007) have treated the subject of cycles by using Geometer's Sketchpad. In the conclusion of the study, most of the students have mentioned that they have like visuality; it is funnier, and treating the subject by the computer, which is inevitable in our age is very useful. It has been concluded that the addition of visuality to the lesson is appreciated by students and teachers and it makes the course more enjoyable.

Ubuz et al. (2009) have conducted a study in which Geometer's Sketchpad-integrated learning medium and a classical teaching medium are used together for the $7^{\text {th }}$-grade students to determine academic successes of students regarding line, angle and polygon and the permanence of these successes. It has been witnessed that while experimental group pays more attention to unimportant properties about geometric shapes, in the last tests, their attitudes have changed, and they have cared about the properties and explanations directly related to the subject. It has been stated that if it is demanded to perceive geometry education as a meaningful activity, then it is necessary to put hypothesis suggestion, analysis, research and reasoning as a part of daily routine of the related courses; it is important to use geometry software accordingly, dynamic geometry particularly, for somehow creation of a geometry lesson culture.

Drawn attention to the existence of many studies (mostly in secondary school level) regarding the effects of geometry software, DeMarinis (2011) has searched the effect of Geometer's Sketchpad use on the students' performance in the problem solutions regarding the whole of polygons' internal angle. The students have been divided into four according to the Solomon-4 group model; two experimental groups have used Geometer's Sketchpad. It has been recorded that according to the last test results, experimental group students are much more successful comparing to the control group members and their success in transmission of the information about the sum of polygons' internal angle.

Önal and Demir (2012), in a study entitled 'The Effect of Computer-aided Education on the Success of Student in $7^{\text {th }}$ Grade', have examined the learning of an experimental group who are taught in an information and technology class by means of Microsoft Picture Manager and a Vitamin program by Ministry of Education in Turkey; as for the control group, they are taught reflection and turning subjects of transformation geometry in classroom medium by using the methods and activities in the present program. In this research, it has been found that using Vitamin and Microsoft Picture Manager to teach transformation geometry has increased students' success compared with classical methods. Computer programs have increased students' motivation and influenced students in a positive manner as they provide much more exercise and practice in much less duration (Serin \& Oz, 2017).

\section{Conclusion}

The eagerness of students for math is related to their motivations. There are some precautions for teachers to increase students' motivation for the course. First, if students learn mathematics meaningfully, this will positively affect their attitudes against the lesson. However, not all students are motivated in the same way. While some get motivation by success, some others may show interest in games, puzzles, strange problems and similar activities, as well as another group of students, pays much attention to the lesson if 
they are given a chance to implement what they have studied or learned. Eventually, it is required to place importance on developing the motivation positively for learning mathematics by taking the individual differences into consideration.

\section{References}

Abrahamson, D. (2004). Embodied spatial articulation: A gesture perspective on student negotiation between kinesthetic schemas and epistemic forms in learning mathematics. In D. E. McDougall \& J. A. Ross (Eds.), Proceedings of the 26th Annual Meeting of the North American Chapter of the International Group for the Psychology of Mathematics Education (Vol. 2, pp. 791 - 797). Toronto, Ontario: Preney.

Aktümen, M., \& Kaçar, A. (2008). Bilgisayar cebir sistemlerinin matematiğe yönelik tutuma etkisi. Hacettepe Üniversitesi Eğitim Fakültesi Dergisi, 35, 13-26.

Armaner, T. (2003). Kaygı kavramı. Kültür Yayınları. İstanbul, 234.

Atabek, E. (2000). Bizim duygusal zekamız. No: 2. Altın Kitaplar Yayınevi. İstanbul

Bandura, A. (1986). Social foundation of thought and action: A social cognitive theory. New Jersey: Englewood Cliffs, Prentice Hall.

Bal, H. (2002). Eğitim teknolojisi kılavuzu. Ankara: Milli Eğitim Bakanlığı Eğitimi Araştırma ve Geliştirme Dairesi Başkanlığı Yayınları.

Baki, A. (2000). Bilgisayar donanımlı ortamda matematik öğrenme. Hacettepe Üniversitesi Eğitim Fakültesi Dergisi, 19, 186-193.

Baki, A. (2002). Dinamik geometri yazılımı cabri ile keşfederek öğrenme. V. Ulusal Fen Bilimleri ve Matematik Eğitimi Kongresi Bildiriler Kitabı, 2(1). 884-891.

Baki, A., Kösa, T., \& Karakuş, F. (2008). Uzay geometri ögretiminde 3D dinamik geometri yazılımı kullanımı: ögrretmen görüşleri. Paper presented at the International Educational Technology, Anadolu Üniversitesi, Eskişehir, Turkey.

Bintaş, J., \& Bağçıvan, B. (2007). İlköğretim yedinci sınıfta bilgisayar destekli geometri öğretimi. Hasan Ali Yücel Ĕ̈itim Fakültesi Dergisi, 7(1), 33-45.

Bozkurt, A., \& Koç, Y. (2012). İlköğretim matematik öğretmenliği birinci sınıf öğrencilerinin prizma kavramına dair bilgilerinin incelenmesi. Kuram ve Uygulamada Eğitim Bilimleri (Educational Sciences: Theory \& Practice), 12(4), 2941-2952.

Burger, W. F., \& Shaughnessy, J. M. (1986). Characterizing the van Hiele levels of development in geometry. Journal for Research in Mathematics Education, 17, 31-48.

Cogill, J. (2003). The Use of Interactive Whiteboards in the Primary School: Effects on Pedagogy Research Bursary Reports Coventry. 52-5. Becta. Retrieved on 12 March 2013from http://www.becta.org.uk/page_documents/research/bursary_projects02-3_summary.pdf.

Dede, Y. (2003). Arcs Motivasyon Modeli'nin Öğrencilerin Matematiğe Yönelik Motivasyonlarına Etkisi, Pamukkale Üniversitesi Ĕ̈itim Fakültesi Dergisi, 2(14), 173- 188.

DeMarinis, M. D. (2011). An interactive geometry program and its effect on elementary student, achievement and understanding on geometry a comparative study. Unpublished Master Thesis, Columbia University, New York, USA.

Ertem, S. (1999). Matematik öğretiminde bilgisayar ve teknolojinin kullanımı üzerine bir inceleme. Unpublished Master Thesis, Dokuz Eylül Üniversitesi, Izmir, Turkey.

Gökbulut, Y., \& Ubuz, B. (2013). Sınıf öğretmeni adaylarının prizma bilgileri: tanım ve örnekler oluşturma. Illkögretim Online, 12(2), 401-412.

Güven, B., \& Karataş, İ. (2003). Dinamik geometri yazılımı cabrı ile geometri öğrenme: öğrenci görüşleri. The Turkish Online Journal of Educational Technology (TOJET), 2(2), 67-78.

Hoffer, A. (1986). Geometry and visual thinking. In T. R. Post (Eds.), Teaching Mathematics in Grades K-8: Research Based Methods (pp. 233-261). Newton, MA: Allyn and Bacon. 
Kabaca, T., Aktümen, M., Aksoy, Y., \& Bulut, M. (2010). Matematk öğretmenlerinin avrasya geogebra toplantısı kapsamında dinamik matematik yazılımı geogebra ile tanıştırılması ve geogebra hakkındaki görüssler. Turkish Journal of Computer and Mathematics Education, 1 (2), 148165.

Karataş, İ., \& Güven, B. (2008). Bilgisayar donanımlı ortamlarda matematik öğrenme: öğretmen adaylarının kazanımları. Paper Presented at 8th International Educational Technology Conference, Eskişehir.

Kaya, Z. (2001). Öğretmenlik mesleğine giriş. Ankara: Pegem yayınları. No: 1, 432.

Keskin, G., \& Orgun, F. (2006). Öğrencilerin öz etkililik-yeterlilik düzeyleri ile başa çıkma stratejilerinin incelenmesi. Anadolu Psikiyatri Dergisi, 7(2), 92-99.

Kösa, T., Karakuş, F., \& Çakıroğlu, Ü. (2008). Uzay geometri öğretimi için üç boyutlu dinamik geometri yazılımı kullanarak çalışma yapraklarının geliştirilmesi. Paper presented at $8^{\text {th }}$ International Educational Technology Conference, 1066-1070

Leung, A. (2012). Discernment and reasoning in dynamic geometry environments. Paper presented at 12th International Congress on Mathematical Education Regular Lectures, Seoul, Korea.

Locke, E.A., \& Latham, G.P. (1990). A theory of goal setting and task performance. Englewood Cliffs, Prentice Hall, New Jersey.

Main, R. (1993). Integrating motivation into the instructional design process. Educational Technology, 33(12), 37-41.

Mart, Ç. T. (2011). How to sustain students' motivation in a learning environment. Retrieved from ERIC database: ED519165.

Mart, Ç. T. (2013a). Commitment to school and students. International Journal of Academic Research in Business and Social Sciences, 3(1), 336-340.

Mart, Ç. T. (2013b). A passionate teacher: Teacher commitment and dedication to student learning.

International Journal of Academic Research in Progressive Education and Development, 2(1), 437-442.

Mart, Ç. T. (2017). Student evaluations of teaching effectiveness in higher education. International Journal of Academic Research in Business and Social Sciences, 7(10), 57-61.

McKeinze, J. (1997). Internet and information readiness. From Now On: The Educational Technology Journal, 6 (7). Retrieved on 10 January 2013, from http://emifyes.iserver.net/fromnow/apr97/indicator.html.

Messick, R. G., \& Reynolds, K. E. (1992). Middle level curriculum in action. White Plains, NY: Longman.

NCTM (National Council of Teachers of Mathematics). (2008). The role of technology in the teaching and learning of mathematics. A Position of the National Council of Teachers of Mathematics. Retrieved on 28 June 2015 from http://www.nctm.org/Standards-and-Positions/NCTMPosition-Statements/

Olkun, S., Altun, A., \& Smith, G. (2005). Computers and 2d geometric learning of Turkish fourth and fifth graders. British Journal of Educational Technology, 36(2), 317-326.

Önal, N., \& Demir, C. (2012). Yedinci sınıflarda bilgisayar destekli geometri öğretiminin öğrenci başarısına etkisi. Turkish Journal of Education, 2(1), 19-28.

Öncü, H. (2001). Sinıf yönetimi. Ankara: Nobel yayın dağıtım, no: 2.

Özden, Y. (2002). Sinıf içinde ögrrenme ögrretme ortamının düzenlenmesi sinıf yönetimi. Ankara: Pegem A Yayıncilik.

Pintrich, P., \& De Groot, V. (1990). Motivational and self-regulated learning components of classroom academic performance. Journal of Educational Psychology. 82(2), 33-40.

Pintrich, P., \& Dale H., S. (1996). Motivation in education. Merill Prentice Hall, A Simon and Schuster Company No: 3, 233, New Jersey.

Schunk, D. H. (1991). Self -efficacy and academic motivation. Educational Psychologist, 26(3-4), 207231. 
Seah, T., \& Bishop, A. (2000). Values in mathematics textbooks: A view through two australasian regions. Paper Presented At The $81^{\text {st }}$ Annual Meeting of The American Educational Research Association, New Orleans, LA (ERIC Document Reproduction Service No.ED 440 870).

Serin, H., \& Oz, Y. (2017). Technology-integrated mathematics education at the secondary school level. International Journal of Social Sciences \& Educational Studies, 3(4), 148-155.

Singleton, C.H., \& Simmons, F.R. (2001). An evaluation of word shark in the classroom. British Journal of Educational Technology, 32(3), 317-330.

Spitzer, D. (1996). Motivation: The Neglected Factor in Instructional Design. Educational Technology, 36(3), 45-49.

Stone, N. J. (2000). Exploring the Relationship Between Calibration and SelfRegulated Learning. Educational Psychology Review, 12 (4), 437-475.

Sutherland, R. (2004). Designs for learning: ICT and knowledge in the classroom. Computers \& Education, 43(1), 5 -16.

Şaban, A. (2002). Öğrenme öğretme süreci: Yeni teori ve yaklaşımlar. Nobel Yayın Dağıtım, No: 2 , Ankara.

Tataroğlu, B. (2009). Matematik ögretiminde akıllı tahta kullanımının 10. Sinıf ögrencilerinin akademik başarıları, matematik dersine karşı tutumları ve özyeterlik. Unpublished Master Thesis, Dokuz Eylül Üniversitesi, İzmir, Turkey.

Tutkun, Ö. F., Öztürk, B., \& Demirtaş, Z. (2011). Matematik öğretiminde bilgisayar yazılımları ve etkililiği. Journal of Educational and Instructional Studies in the World, 1(1), 133-139.

Ubuz, B., Üstün, I., \& Erbaş, A. K. (2009). Effect of dynamic geometry environment on immediate and retention level achievements of seventh grade students. Eurasian Journal of Educational Research, 35, 147-164.

Usiskin, Z. (1982). Van Hiele levels and achievement in secondary school geometry. (Final report of the Cognitive Development and Achievement in Secondary School Geometry Project.) Chicago: University of Chicago.

Uyar, A. (2007). Bilgisayar ve ögretim teknolojileri ĕ̌itimi anabilim dalı endüstri meslek liseleri birinci sinı öğrencilerine teknik resim dersinde temel kavramların bilgisayar destekli çizim programları (cad) ile anlatılmasının akademik başarlya ve kalıcılı̆̆a etkisi. Unpublished Master Thesis, Çukurova Üniversitesi, Adana, Turkey.

Üredi, I. (2005). Algılanan anne baba tutumlarının ilkögretim 8. sınıf öğrencilerinin öz- düzenleyici ögrenme stratejileri ve motivasyonel inançları üzerindeki etkisi. unpublished Doctoral Dissertation, Y.T.Ü. İstanbul, Turkey.

Wood, R., \& Ashfield, J. (2008). The use of the interactive whiteboard for creative teaching and learning in literacy and mathematics: a case study. British Journal of Educational Technology, 39(1), 84-96.

Wu, H.K., \& Huang Y.L. (2007). Ninth-grade student engagement in teacher centered and Studentcentered Technology - enhanced learning Environments. Willey Periodicals, Science Education. 91, 727-749.

Yalın, H. İ., (2000). Öğretim teknolojileri ve materyal geliştirme. Ankara: Nobel Yayın Dağıtım.

Yin, Y., Shavelson, J., \& Ayala, C. (2008). On the impact of formative assessment on student motivation, achievement, and conceptual change. Applied Measurement in Education, 21(4), 335-359. 